Л.А.Ситніченко,

кандидат філософських наук, старший науковий співробітник Інституту філософії імені Г.С.Сковороди НАН України

\title{
ТРАНСФОРМАЦІЯ ФІЛОСОФІЇ СПРАВЕДЛИВОСТІ: ВІД ПРИНЦИПІВ СПРАВЕДЛИВОСТІ ДО ЇЇ ОСНОВНОГО ПИТАННЯ
}

Філософія справедливості, як філософія загалом, допомагає якщо не змінити світ на краще, то побачити та осмислити його поза спрощеною дилемою індивідуального та соціального буття, права та блага і віднайти шляхи виходу зі складних, навіть кризових ситуацій. Який шлях обрати для подолання невизначеності, непевності сучасного світу і що пропонує нам на сьогодні філософія справедливості, як відповідає вона на «нездужання модерну» та «суспільство ризику»? Чи достатньо, як вважав вже І.Кант, «подумки ставити себе на місце іншого», а для успішного функціонування складного сучасного суспільства плекати таку чесноту як справедливість?

Всебічне глибоке осягнення справедливості, дискусії навколо проблем соціальної справедливості започатковане «Теорією справедливості» Дж.Ролза та підсумоване в його ж «Справедливості як чесності». Йдеться про розбудовану Ролзом життєздатну теоретичну конструкцію, яка уможливлює уникнення як некритичної підтримки несправедливого суспільного ладу, так і його радикальної зміни, революційного зламу. Концепції Ролза безумовно притаманний вагомий змістовний та методологічний потенціал для створення гармонійного соціального простору, проте вона потребує розвитку та доповнень, особливо за необхідності врахування нового соціального досвіду.

Виступаючи проти утилітаризму, з одного боку, та проти аксіологічного скептицизму, з іншого, Ролз йде шляхом інтерсуб'єктивного тлумачення кантівського поняття автономії, намагаючись поєднати свободу та рівність і надати поняттю справедливості статусу нормативного фундаментального поняття. 3 метою подолання відчуження людини від владних інституцій Дж.Ролз до останніх днів свого життя працював над обгрунтуванням можливості вільного та справедливого, чесного людського буття. На початку своєї праці Ролз постулює перевагу справедливості, права перед благом: «Кожна 
особистість має засновану на справедливості недоторканість, від якої вона не може відмовитися навіть заради блага всього суспільства. 3 цієї причини справедливість не допускає того, щоб втрату свободи одними людьми було виправдано більшими благами інших. Не дозволено, щоб злигодні, до яких змушено суспільну меншість, були ціною тих переваг, якими користується більшість суспільства» $[1$, 27]. На думку Ролза, не можливо пожертвувати індивідуальними правами навіть заради загального добробуту.

Так витлумачивши ідею справедливості, автор робить наступний крок - з'ясовує не так моральний, етичний сенс справедливості, як iï підвалини. І в цьому напрямі зрозумілою стає основна теза сучасної ліберальної соціально-філософської концепції, а саме - справедливе та вільне суспільство, яке люди створюють за своїми власними намірами та інтересами, за уявленнями про благо, існує на засадах справедливих принципів. І пріоритет справедливості в ньому полягає не в тому, що вона визначає собою якусь єдино правильну мету, а в тому, що сама є цією метою. Таке розв'язання дилеми - право чи справедливість - спирається на кантівське розуміння права як моралі, що регламентує насамперед діяльність правителя, а також на інтерпретацію справедливості як формальної загальної рівності вільних та незалежних один від одного людей. Адже тільки такі люди можуть бути суб'єктами права. До того ж таке розуміння права базується на обстоюванні індивідуальних прав так само, як і на доведенні необхідності для суспільства правової держави.

Звідси випливає і справедливість як загальна правова основа, що «панує» над усіма часто протилежними реальними інтересами, регулює, «вимірює» їх єдиною, спільною правовою міркою. Йдеться про інші, ніж, скажімо, у Гобса, антропологічні висновки, які свого часу прагнув розгорнути Кант і які тепер застосовує у своїй теорії Ролз. За Кантом, їх сутністю має бути інтерпретація людини як принципово здатної стати самостійною та вільною.

Концепція Ролза присвячена не просто вирішенню власне проблеми справедливості. Вона є наслідком грунтовного дослідження справедливості суспільного ладу та його інституцій як проблеми, яка виникає за умов суперечності останніх інтересам членів суспільства, а також суперечності інтересів, прав та прагнень членів цього суспільства між собою. Вже завдяки двом основним принципам справедливості означена концепція є водночас і соціально-філософською стратегією свободи. 
Теорія «справедливості як чесності» розпочинається», по-перше, зі спільного неупередженого вибору «першопринципів концепції справедливості, яким належить регулювати всяку подальшу критику й реформу інституцій» $[1,38]$. Проте ми мусимо йти далі й визнати ту важливу обставину, що може стати засновком позитивної моделі політичної антропології. Йдеться про вільних, рівноправних та чесних індивідів, які добровільно беруть на себе певні зобов'язання та обирають два основні, вже загальновідомі принципи справедливості. «Інтуїтивна ідея тут та, що, оскільки добробут кожного грунтується на певній схемі співпраці, без якої нікому б не мати задовільного життя, то розподіл переваг має бути такий, щоб викликати у всіх, хто бере в ньому участь, включно і з тими, що перебувають у гіршому становищі, готовність до співпраці» $[1,41]$. Два виокремлені Ролзом принципи справедливості $[15,31]$ видаються йому справедливою основою, на якій краще обдаровані чи щасливіші у своєму соціальному становищі (причому не можна сказати, ніби ми заслужено маємо те чи те) можуть сподіватися на добровільну співпрацю 3 іншими людьми. Ці принципи стосуються справедливого розподілу не лише економічних благ та можливостей, а й основних прав і свобод. Визначаючи основні свободи як свободу думки й свободу совісті, політичні свободи, свободу об'єднань, а також свободи, що визначаються свободою і недоторканістю особи, Ролз зазначає, що не надає ніяких переваг свободі як такій. На його думку, ця загальна презумпція свободи не створює ніяких підстав для переваг будь-якої конкретної свободи, а наведений перелік основних свобод $є$ невід'ємною рисою філософської концепції справедливості та свободи. Сформульовані ним два принципи справедливості уможливлюють найглибше розуміння взаємозв'язку свободи та рівності в демократичному суспільстві. А тривожна непрозорість майбутнього може стати основою згоди будь-якої людини на максимізацію соціального та матеріального мінімуму за допомогою соціальних правил, податкової політики, благодійних товариств та фондів.

Ролз не має ілюзій щодо громадян сучасного суспільства: це далеко не наївні моралісти, що вірять у можливість утворення якоїсь (відомої лише небагатьом філософам) «етичної спільноти» чи досягнення інших «рожевих» ідеалів. Кожен з них прагне здійснення своїх власних інтересів та намірів. Якщо вже сам факт спільного існування людей має своїм наслідком прагнення свободи, яка призводить до конкуренції, а іноді й до конфлікту інтересів, то цілком 
природно запровадити певну процедуру справедливого функціонування соціальних інституцій. Такий підхід Ролз називає методом «чистої процедурної справедливості».

Істотним для розуміння теорії «справедливості як чесності» $\epsilon$ також і те, що ії підвалиною є теорія «суспільної угоди». Ролз вважає, що держава та інші соціальні інституції мають право на обмеження свободи громадян, якщо це обмеження є необхідним та справедливим. Згода певної кількості вільних людей на об'єднання в межах певної спільноти виступає його справжнім витоком. Дискурс свободи та справедливості Ролза не просто розгортається в річищі теорії суспільної угоди, він повертає цю теорію «обличчям до життя» і розглядає цю угоду як домовленість, але досить широку, тобто таку, що $є$ джерелом, механізмом справедливого обстоювання суспільних інтересів, основою принципів справедливості. А добре організоване суспільство має кілька характерних рис: воно регулюється загальновизнаною концепцією справедливості, яку визнають всі громадяни даного суспільства, їй відповідають і основні соціальні інституції. Сама ж концепція справедливості має грунтуватися на розумних принципах та загальновизнаних методах їх формулювання. Адже члени суспільства мусять бути моральними, рівними та вільними особистостями.

Опираючись на вчення І.Канта про неможливість ставитися до людей як до засобу, Ролз і формулює принцип «соціального мінімуму». У ньому він стверджує, що «всі соціальні цінності: свобода й можливість, прибуток і багатство, а також соціальні основи самоповаги, мають розподілятися порівну, якщо тільки нерівний розподіл деяких, чи й усіх, цих цінностей не є всім на користь» $[6,104]$. А основна мета цього принципу полягає в тому, щоб додати до перспектив найменш успішних його членів ще й самоповагу. Таким чином, запропоновані Ролзом принципи справедливості все ж варто вважати також принципами, механізмами взаємозв'язку людської гідності та соціальної справедливості. У цьому річищі, річищі поваги до людини, повинні рухатися важливі новітні способи обгрунтування існування необхідного для людей певного соціального мінімуму. Адже вимога соціального забезпечення (через інституції соціальної держави) може розглядатися як те, що справедливо належить кожній людині.

Критичне осмислення процедурно-розподільної моделі справедливості й призводять до утворення іiі нового образу, який враховує (відсутні в теорії Дж.Ролза) проблеми влади, відповідальності, нове бачення розподілу та визнання. Лише після розуміння сутності та 
меж ідеї розподілу варто зробити наступний крок - до пошуку сучасного образу соціальної справедливості та відповіді на запитання про те, як ми можемо тлумачити соціальну справедливість, коли ідея розподілу матеріальних благ є недостатньою (через супровід іiі патерналізмом, популізмом, авторитаризмом і т.п.) для всебічного визначення соціальної справедливості?

У цих пошуках особливе місце належить роздумам А.Гонета, який знову і знову звертається саме до проблеми соціальної справедливості. Про що свідчать його останні праці. Так, вступ до найгрунтовнішої з них «Право свободи» [2] не лише має назву «Теорія справедливості як аналіз суспільства», а й підсумовує зроблене дослідником у цій царині раніше, зокрема у праці «Я серед інших» [3] та спільній з Н.Фрайзер праці «Перерозподіл чи визнання?» [4]. Йдеться не лише про критичне осмислення Гонетом розподільної моделі справедливості Дж.Ролза, а і про шляхи розвитку, доповнення комунікативного філософування Ю.Габермаса за допомогою поняття «усвідомлення несправедливості», яке втілюється у відчутті невідповідності суспільства чуттю справедливості, втіленому в неписаній суспільній моралі. Адже насправді досвід соціального страждання та втрачених надій може зруйнувати легітимність суспільних інституцій. Аналізуючи в статті «Соціальна динаміка зневаги» комунікативну парадигму Ю.Габермаса, Гонет окреслює іiі суттєві внутрішні недоліки: відсутність в ній морального досвіду дієвців. Уже зі своєї першої відомої праці «Критика влади» Гонет розпочинає трансформацію комунікативної парадигми в річище визнання. Саме в контексті останнього суб'єкти соціальної взаємодії спілкуються в горизонті взаємних очікувань визнання себе в якості моральних та соціально цінних індивідів. В осмисленні «динаміки соціальної зневаги, презирства» (у праці «Інше справедливості») Гонет наголошує: «Суб’єкти сприймають інституційні процеси як соціальну несправедливість тоді, коли вони бачать, що ці процеси втілюють зневагу до тих вимірів їх особистості, на визнання яких вони, з їх точки зору, мають право» $[5,156]$.

Перш ніж зупинитися на запропонованій Гонетом теорії соціальної справедливості, поставимо запитання методологічного сенсу: які ж зміни, на думку дослідника, властиві сучасній теорії справедливості та які завдання стоять перед нею, як і політичною філософією загалом? Зосередження уваги лише на нормативних принципах та дистанціювання від аналізу суспільства - головний недолік сучасної 
політичної філософії. Проте «не можна стверджувати, що формулювання нормативних, які є мірилом моральної легітимності суспільного ладу, не $\epsilon$ завданням теорії справедливості» [2, 18]. Варто лише застерегти від штучного їх формулювання, а потім - «застосування» до існуючих практик та інституцій, що лише поглиблює прірву між тим, що є, та тим, що мусить бути. Що ж пропонує сам Гонет та як це обгрунтовує?

На його думку, йдеться про необхідність враховувати забуту кантівської традицією в тлумаченні принципів справедливості проблему тісного зв'язку нормативних принципів, які слугують розумінню міри моральної легітимації суспільного ладу, з основним суспільними інституціями, а також про усвідомлення того, що суб'єкт $\epsilon$ не лише адресатом загальних норм, а і їх творцем спільно з іншими людьми. I все це важливо саме для розуміння проблеми соціальної справедливості, адже ми висновуємо себе не лише із себе, а й iз взаємин $з$ іншими людьми, які оцінюють нас так, як ми можемо оцінити, поважати їх. Замість благ (про які говорить розподільна справедливість і які є також важливими), ми мусимо говорити про взаємини визнання, а замість розподілу думати й про інші шляхи здійснення справедливості, як не «є такою собі матерією, від якої ми маємо якийсь шматок, розміри якого залежать від рішення якогось суб'єкта чи групи» $[3,51]$.

Уже у праці «Боротьба за визнання» [6] Гонет говорить про «радикальну зміну перспективи дослідження» $[6,270]$, про істотне значення моральних конфліктів, про значення форм зневаги (які починаються 3 другого (громадянсько-правового рівня) для соціальної боротьби. А також про значення самоповаги, чуття власної гідності (з посиланням і на параграф 67 «Теорії справедливості» Дж.Ролза [6, 598-599]) - про взаємини визнання в дистрибутивній парадигмі справедливості та нового, інтерсуб' єктивного розуміння свободи, що й набуло свого подальшого розвитку в «Праві свободи».

Для розуміння поглядів Гонета безумовно важливою стала запропонована ним структура $[6,211]$ соціальних обставин визнання та форми останнього, що втілюються не в правовому полі суспільного буття, а й у ставленні людини до самої себе, усвідомленні власної цінності.

Проте варто зупинитися насамперед на формах зневаги, які зазіхають, порушують (і не лише на думку Гонета) головне, що є в людині - iii гідність [6, 212-213]. Гонет наголошує на тому, що най- 
деструктивніше втручання в ставленні людини до самої себе зумовлене ії неспроможністю самостійно розпоряджатися своїм тілом, що супроводжується втратою довіри і до себе, і до світу загалом. А досвід людини про неможливість користуватися належними їй правами призводить до втрати самоповаги, тобто здатності ставитися до себе як рівноправної особистості. Третім же різновидом приниження $є$ соціальне приниження, тобто применшення, недооцінка соціального статусу індивіда, його соціальної цінності через спотворену систему цінностей.

Зауважимо, що тут ще не йдеться про необхідний для існування та розвитку людини матеріальний мінімум, на чому наголошують інші відомі автори - і А.Сен, і Н.Фрейзер, і Е.Тугендгат. Саме вони стали захисниками тих, хто залишається за межами «основних принципів» справедливості Дж.Ролза - слабких, малих, немічних. А.Гонет досліджує проблему праці та визнання в доповіді «Справедливість та комунікативнв свобода», а у праці «Я серед інших» [3, 78-102] пропонує спробу нового бачення цієї проблеми. Адже несправедливо обділеними та бідними («бідні, які працюють») можуть стати і дорослі члени суспільства, на що й звертає увагу американський філософ Ненсі Фрайзер (що викладено в їх спільній з А.Гонетом вже згаданій вище праці «Перерозподіл чи визнання?» [4, 13-128]). Н.Фрайзер розгортає «дуалістичну», або «двовимірну» теорію соціальної справедливості, що означає доповнення, органічний взаємозв’язок справедливого вирішення проблеми визнання справедливим перерозподілом суспільних благ та цінностей. Справедливість обіймає собою два аспекти: i визнання, і перерозподіл (на відміну від Гонета, Фрайзер не вважає відсутність лише визнання головною причиною патологій суб'єктивності). На іiі думку, ми мусимо говорити про необхідність одночасного усунення економічної нерівності та культурного, гендерного та ін. приниження. Проте до прояви «Права свободи» А.Гонета та останніх досліджень Р.Форста так і не було чітко сформульовано головне питання філософії справедливості. Питання, яке свідчило б про зміни, властиві сучасній теорії справедливості, і про ті нові завдання, які постають перед нею, як і перед політичною філософією загалом.

Варто погодитися з тим, що зосередження уваги лише на нормативних принципах та дистанціювання від аналізу суспільства головний недолік сучасної політичної філософії. Водночас, «не можна стверджувати, що формулювання нормативних, які є мірилом 
моральної легітимності суспільного ладу, не є завданням теорії справедливості, варто лише застерегти від штучного їх формулювання, а потім - «застосування» до існуючих практик та інституцій, що лише поглиблює прірву між тим, що та тим, що мусить бути $[2,14]$. Спираючись насамперед на «Засади метафізики звичаїв» І.Канта, де наголошується на органічному зв'язку ідеї свободи з поняттям автономії, Гонет визначає рефлексивну свободу як моральній обов'язок поводитися з іншими суб'єктами як з автономними, якщо я очікую від них такого ж ставлення до себе $[2,65]$. Наступним кроком у тлумаченні рефлексивної свободи стало розуміння іiї як взаємин автономії та автентичності, а також інтерсуб'єктивне корегування рефлексивного підходу. Йдеться про усвідомлення того, що суб'єкт $є$ не лише адресатом загальних норм, а і їх творцем спільно 3 іншими людьми. I все це важливо саме для розуміння проблеми соціальної справедливості. Адже на ідеї моральної автономії засновані всі процедурні концепції справедливості (про це свідчить параграф 24 «Теорії справедливості» Ролза [1, 196-204]), які грунтуються на тезі про чесність, а справедливість тлумачиться як результат колективного самовизначення, тобто ідея моральної автономії стає осердям процедурних концепцій.

Поступово в осмисленні проблеми розподілу головний акцент робиться на тому, що це є власне політична, владна проблема (А.Сен, наприклад, чітко визначає проблему голоду як політичну проблему). Ці роздуми тісно пов'язані і з вітчизняними реаліями, де ще донедавна інтерпретація дієвості політичної легітимації (а насправді уявлення про шляхи досягнення соціальної справедливості) трималася та й продовжує триматися на вдало означеній О.Білим «готовності індивіда передоручити іншому власний клопіт, зміст якого становлять різноманітні фобії, ресантимент, жадоба влади. На обіцяний претендентами (в президенти, депутати і т.П. - Л.С.) світ проектуються мрії індивіда про царство справедливості, де ресантимент, несамовита заздрість знаходять вихід у цілковитій безкарності за порушення табу, у покаранні «об’ єкта заздрості» [7, 21]. В означене світобачення вписується мрія (чи культ) про суворого та справедливого господаря. До того ж, лише час та зусилля кожного на подолання страху та тривоги за власну долю та долю країни покажуть, чи вдасться нам уникнути дилеми порядку та хаосу, витлумачених у сучасній масовій свідомості наступним чином: порядок «відіграє роль своєрідного протезу, узвичаєння, яке автоматизує соціальну 
поведінку. Натомість хаос і безлад для посттоталітарного індивіда неминуче пов'язується 3 перманентним конфліктом інтересів, а отже, 3 демократичними практиками розв'язання цих конфліктів на інституційному рівні» $[7,22]$.

А.Гонет виокремлює наступні основні складові майже всіх сучасних теорій справедливості: процедуралізм, ідея розподільної справедливості та уявлення про державу. Критичний дискурс варто розпочати саме 3 розуміння розподільної справедливості, яка $є$ осердям двох інших означених складових нормативних теорій справедливості.

Саме такий критичний дискурс пропонує нам відомий представник знаменитої Франкфуртської школи Райнер Форст. Вже реконструкція (у праці «Контексти справедливості») основних суперечностей між ліберальним та комунікативним тлумаченням соціального буття та справедливості привела Р.Форста, до створення власної, «конструктивістської теорії справедливості», яка підсумовує суперечки в цій царині та спирається передусім на особливий образ людини, яка витлумачується як істота, принципово здатна до виправдання, обгрунтування. Йдеться про розлогу відповідь на запитання: за яких обставин примусові норми можуть бути справедливими? Чому ми мусимо коритися їм - для природності та добровільності нашої покори та чуття справедливості суспільного примусу останній мусить бути доведений, виправданий в якості справедливого?

Лейтмотивом цілої низки праць Форста останніх років стало визначення основного права людини, права на виправдання. Йдеться про право кожної людини опротестувати несправедливі норми та дії за відсутності переконливих аргументів на користь справедливості останніх. Право на виправдання, моральне, найзагальніше та засадниче, - це право кожної людини виступити з протестом проти певних (переважно репресивних) норм, дій чи претензій, якщо їй не будуть надані належні аргументи на користь легітимності, справедливості означених норм $[8,10]$. Його розуміння соціальної справедливості базується на тезі про те, що наше право на виправдання, обгрунтування є осердям, засадою легітимної, справедливої влади, суспільного ладу. Разом з Форстом ми мусимо говорити не лише про здатність людини виправдовувати перед іншими свої вчинки та переконання (тобто відповідати за них), а і про взаємну обов'язковість таких дій. Лише в такому контексті можливе адекватне осягнення соціальних практик, соціального буття загалом. Більше того, ми мусимо також (навіть в межах розподільної справедливості) впильнувати 
політичний сенс соціальної справедливості і через цю теоретичну пильність полишити іiі абстрактно-фальший образ, який зважає лише на те, що нам чогось бракує, а не на справжні причина людської упослідженості та бідності.

Розмірковуючи про справедливість, Форст наголошує на тому, що він звертається насамперед до розгляду проблеми політичної та соціальної справедливості, тобто якості основних принципів та структур соціальної взаємодії людей, а також, що основні образи справедливості, які обіймають собою розмаїття конкретних уявлень, неможливо помислити, уявити без несправедливості. Осердям останньої $є$ не так брак тих чи інших благ чи цінностей, як нехтування людиною (як тут не пригадати «Ідею справедливості» А.Сена чи теорію справедливості А.Гонета) в процесі виготовлення та розподілу цих істотних суспільних благ. Насправді, найістотнішим для упорядкування людського життя (в його взаємодії та конфліктах 3 іншими людьми) нормативним поняттям $є$ поняття справедливості. Наступна особливість тлумачення соціальної справедливості Р.Форстом полягає в тому, що ми мусимо не лише з'ясувати, на які права та блага ми можемо претендувати, а й усвідомити себе одночасно як авторами, так і адресатами справедливості. У загально-методологічному сенсі йдеться про інше тлумачення самого суб'єкта справедливості.

Зауважимо також, що, виокремлюючи поняття соціальної справедливості, розмірковуючи над її суб'єктом, Форст виходить 3 того, що справедливим $є$ той суспільний лад, в якому правила соціальної взаємодії та соціальні інституції $є$ вільними від свавільного панування, а всі учасники соціальної взаємодії визнаються вільними та рівними. Не зважаючи на те, що Форст не забуває про розподільну справедливість як розподіл матеріальних благ на засадах загальнолегітимних правил, він наполягає на рефлексивній природі справедливості, яка не обмежується тезою про те, яку частку від цілого має та чи інша людина, або ж може чи не може мати. Йдеться про відповідальність людини за свої вчинки та переконання. У політичному сенсі суспільне життя має регулюватися справедливими (виправдами, обгрунтованими) нормами та інституціями. I громадяни (у демократичних суспільствах) є як авторами, так і адресатами процесу обгрунтування, виправдання. Свавільна влада - це влада без легітимних засад, тож боротьба проти несправедливості $\epsilon$ боротьбою саме проти такого стану справ.

Важливими є також спроби Форста пов’язати справедливість 
та гідність людини: справедливість не випадково пов'язана з чесністю, взаємодією, симетрією та рівністю. Людина, якій притаманна гідність, мусить прагнути, вимагати виправдання (існуючих суспільних інституцій). «І жертвами несправедливості є насамперед не ті особи, яким бракує певних благ, а ті, на яких не зважать при створенні та розподілі цих благ» $[8,274]$. І розподіл основних суспільних благ (осердя розподільної моделі справедливості) залежить від проблеми влади. А за межами осмислення владних проблем (iii сутності) здійснення справедливості виглядає як великодушна допомога, а не вимога справедливості. І в такий спосіб люди перетворюються із суб'єктів на об'єкти справедливості, а потім - на об'єкти щедрої турботи.

Хто ж буде здійснювати цей справедливий розподіл, якщо в суспільстві зазвичай немає таких авторитетів? Йдеться про тісний зв'язок, взаємозв'язок власності і відносин. Визначаючи справедливість як певну якість соціальних взаємин та інституцій, як політичну, а не гуманітарну проблему, Форст наголошує на тому, що соціальна, політична справедливість стосується передовсім соціальних відносин і проблем влади: «Перше питання справедливості це питання влади. Адже йдеться не лише про те, як, справедливо чи ні, розподіляються якісь блага, а і про те як ці блага створені, хто визначає їх розподіл та здійснює його» $[8,280]$. Розгортаючи основне, владне питання соціальної справедливості, в останній своїй праці Р.Форст зазначає: «хто говорить лише про розподіл суспільних благ концентрує увагу на їх недостатності, забуває про те, що цих благ бракує через економічну чи політичну експлуатацію» $[9,172]$.

Таким чином, окреслюючи принципово різні образи справедливості, Р.Форст, як і О.Гьофе, критикує розподільні концепції справедливості та стверджує, що вони залишають поза увагою того, хто розподіляє блага. Такий, зорієнтований на розподілі суспільних благ, погляд не зважає на проблеми несправедливості, на те, що злидні є наслідком економічної та політичної експлуатації, економічних та політичних зловживань. Адже перше питання справедливості - це питання влади, питання про витоки несправедливих соціальних відносин. А гідність людини порушується тоді, коли людина вважається лише отримувачем розподілюваних благ, а не самостійним суб'єктом справедливості. Чітко виокремлюючи не лише основне питання соціальної справедливості, а й іiі основне завдання, Гонет звертається до роздумів Дж.Ролза. I зауважує, що 
вже в «Теорії справедливості» Ролз стверджував: «Людей, котрі дотримуються різних уявлень про справедливість, може об'єднати наступне: інституції є справедливими тоді, коли при визначенні основних прав та обов'язків не робиться ніяких свавільних розрізнень між людьми, а правила встановлюють належну рівновагу конкуруючих домагань на користь суспільного життя» [1,29]. Справедливість - це найістотніша протилежність сваволі, свавільна влада це влада людини над людиною без легітимних підстав, а боротьба проти несправедливості - це боротьба проти такої влади. Справедливість вимагає: люди $\epsilon$ рівноправними учасниками соціального $\mathrm{i}$ політичного порядку, в якому люди гідні того, щоб разом визначати умови розподілу суспільних благ. Справедливим же $\epsilon$ той суспільний лад, правила та інституції якого «є вільними від різних форм свавільної, зумисної влади. А убезпечення від цього і є першим завданням справедливості» $[8,170]$.

Зауважу, що ідеї «конструктивістської теорії справедливості» Р.Форста та «справедливості як визнання» А.Гонета $є$ досить плідними і потребують свого подальшого дослідження. Проте для розуміння проблеми соціальної справедливості на вітчизняному просторі варто зважити на працю Дугласа Норта «Насилля та соціальні порядки» [10], яка спрямована на виокремлення основних моделей суспільного ладу та аналіз умов можливості переходу від «порядку обмеженого доступу» (де соціальні відносини базуються на особистих стосунках, а в усьому домінує привілейована еліта, яка всі свої зусилля спрямовує на обмеження доступу до економічних і політичних ресурсів) до «порядку вільного доступу» (в якому існує громадянське суспільство, низка інституцій та противаг, що унеможливлюють сваволю влади). То ж залишається не лише сподіватися, а й прагнути до того, щоб ми спромоглися зробити такий перехід, а соціальна справедливість стала не лише регулятивним принципом, а і соціальною реальністю. Адже ситуація, в якій ми знаходимося, свідчить про прихід нової епохи, в котрій наміри людини віднайти усталені орієнтири для розбудови свого життя є застарілими через невизначеність цих орієнтирів, їх постійну підвладність численним змінам та відсутність наперед заданих «референтних груп». То ж потрібно не лише критикувати соціальний проект Модерну, а й оберігати та розвивати далі такі важливі його досягнення, як демократичні свободи, права людини та правова держава. 


\section{ЛIТЕРАТУРА}

1. Ролз Дж. Теорія справедливості. - К., 2001. - 822 с.

2. Honneth A. Das Recht der Freiheit. Grundriss einer demokratischen Sittlichkeit. - Berlin, 2013. - $628 \mathrm{~s}$.

3. Honneth A. Das Ich in Wir. Studien zur Anerkennungstheorie. - Berlin, 2010. - $308 \mathrm{~s}$.

4. Fraser N., Honneth A. Umverteilung oder Anerkennung? Eine politisch philosophiesche Kontroverse. - Frankfurt am Main, 2003. - $306 \mathrm{~s}$.

5. Honneth A. Das Andere der Gerechtigkeit. Aufsätze zur Praktischen Philosophie. - Frankfurt am Main, 2003. - 340 s.

6. Honneth A. Kampf um Anerkennung. Zur moralischen Grammatik sozialer Konflikte. - Frankfurt am Main, 2000. - $301 \mathrm{~s}$.

7. Білий O. Політична легітимація і насильство // Філософська думка, 2013. - №2, - C.9-26.

8. Forst $R$. Das Recht auf Rechtfertigung. Elemente einer konstruktivistischen Theorie der Gerechtigkeit. - Frankfurt am Main, 2007. - $413 \mathrm{~s}$.

9. Forst R. Normativität und Macht. Zur Analyse sozialer Rechtfertigungsordnungen. - Berlin, 2015. - $254 \mathrm{~s}$.

10. Норт Д., Уоплис Д., Вайнгаст Б. Насилие и социальные порядки. Концептуальные рамки для интерпретации письменной истории человечества. - М., 2011. - 223 с.

Ситніченко Л.А. Трансформачія філософії справедливості: від приничипів справедливості до ї̈ основного питання.

У статті досліджується трансформація сучасної філософії справедливості від пошуку основних принципів соціальної справедливості до формулювання ії̈ основного питання. Встановлено, що в умовах кризового суспільства не лише справедливість, а й сучасне буття загалом, мають розглядатися критично і контекстуально: наші уявлення мусять виводитися не апріорним шляхом, а реконструюватися як умови можливості відтворення справедливого соціального буття. Доведено, що подоланню переважно нормативістської спрямованості сучасної теорії справедливості послужили праці А.Гонета, Р.Форста, Н. Фрайзер, А.Сена, які наблизили осмислення соціальної справедливості до сутнісного суспільного аналізу. Критичне осмислення в сучасній політичній філософії процедурно-розподільної моделі справедливості призвело до утворення іiї нового образу, який зважає на відсутні в теорії Дж.Ролза проблеми влади, відповідальності, визнання, людської гідності. У статті з'ясовано, що в дослідженні проблеми розподілу суспільних благ необхідно акцентувати увагу на його політичній складовій, що й дозволить зрозуміти справжній сенс і основні завдання 
соціальної справедливості. Обгрунтовується теза про те, що за межами осмислення владних, політичних вимірів соціальної справедливості люди перетворюються із суб'єктів справедливості на ії об'єкти. Проаналізовано «конструктивістську теорію справедливості» Р.Форста, а також доведено, що для розуміння проблеми соціальної справедливості плідною може стати теорія Д.Норта, яка спрямована на аналіз умов можливості переходу від доіндустріального до сучасного, постіндустріального соціального «порядку вільного доступу».

Ключові слова: справедливість, соціальна справедливість, розподільна справедливість, влада, визнання, гідність.

Ситниченко Л.А. Трансформащия философии справедливости: от принципов справедливости кее основному вопросу.

В статье исследуется трансформация современной философии справедливости от поиска основных принципов социальной справедливости к формулированию ее основного вопроса. Доказано, что в условиях кризисного общества не только справедливость, но само общество должны рассматриваться критически и контекстуально: наши представления о них должны выводиться не априорным путем, а реконструироваться как условия возможности создания справедливого общественного бытия. Доказано, что преодолению преимущественно нормативистской направленности современной теории справедливости послужили работы А.Хонета, Р.Форста, Н.Фрайзер, А.Сена, которые приблизили осмысление социальной справедливости к сущностному общественному анализу. Критическое осмысление в современной политической философии процедурно-распределительной модели справедливости привело к образованию ее нового образа, который обращает внимание на отсуствующие в теории Дж.Роулза проблемы власти, ответственности, признания, человеческого достоинства. В статье речь идет также о том, что при исследовании проблемы распределения общественных благ необходимо акцентировать внимание на его политической составляющей, что и позволит понять настоящий смысл и основные задачи социальной справедливости. Обосновывается тезис о том, что за пределами осмысления властных, политических измерений социальной справедливости люди превращаются из субъектов справедливости в ее объекты. Проанализировано «конструктивистскую теорию справедливости» Р.Форста, а также доказано, что для понимания проблемы социальной справедливости плодотворной может стать теория Д.Норта, в которой анализируются условия возможности перехода от доиндустриального к современному, постиндустриальному социальному «порядку открытого доступа».

Ключевые слова: справедливость, социальная справедливость, распределительная справедливость, власть, признание, достоинство. 
Sytnichenko L. Transformation of the philosophy of justice: from the principles of justice to its main issue.

The article examines the transformation of the modern philosophy of justice from the search for the basic principles of social justice to formulate its main issue.

It is established that in circumstances of crisis society, not only justice, but the present life as a whole, should be considered critically and contextually: our images must be deduced not by a priori way, but be reconstructed as conditions for the reproduction of a justified social being. It has been proved that the work of A.Honneth, R.Forst, N.Fraser, A.Sen, which brought social justice to the essence of social analysis, served to overcome the normative orientation of modern theory of justice. A critical comprehension in the modern political philosophy of the procedural-distributional model of justice has led to the formation of its new image, which takes into account the problems of power, responsibility, recognition, human dignity that are missed in the theory of J.Rawls the problems of power, responsibility, recognition, human dignity. The article clarifies that in the investigating of the problem of the distribution of social goods, it is necessary to focus on its political component, which will allow us to understand the true meaning and basic problems of social justice. The thesis is based on the fact that people are transformed from the subjects of justice into its objects beyond the comprehension of the power, and political dimensions of social justice. The article analyzes the «constructivist theory of justice» by R.Forst, and also it is proved that for understanding the problem of social justice, the theory of D.North can be useful, as is aimed at analyzing the conditions for the transformation from preindustrial to modern, post-industrial social «order of free access».

Key words: justice, social justice, distributive justice, power, recognition, dignity. 